\title{
Penerapan Model Pembelajaran Think Pair Share dengan Permainan Puzzle untuk Meningkatkan Kemampuan Berpikir Kritis Matematika Kelas IV SD
}

\author{
${ }^{1}$ Rosita Nurul Hidayah, ${ }^{2}$ Bambang Suteng Sulasmono, ${ }^{3}$ Eunice Widyanti \\ Pendidikan Guru Sekolah Dasar, Universitas Kristen Satya Wacana, Salatiga, Indonesia \\ 1292015061@student.uksw.edu, ${ }^{2}$ sulasmonobambang@yahoo.com, ${ }^{3}$ eunicewidyanti@uksw.edu,
}

\section{INFO ARTIKEL}

Riwayat Artikel:

Diterima:15-03-2019

Disetujui:30-04-2019

\section{Kata Kunci:}

Think Pair Share

Permainan Puzzle

Berpikir Kritis

\section{Key Words:}

Think Pair Share

Puzzle Game

Critical Thinking

\begin{abstract}
ABSTRAK
Abstrak: Penelitian ini bertujuan untuk mendeskripsikan penerapan model pembelajaran Think Pair Share (TPS) dengan permainan puzzle untuk meningkatkan kemampuan berpikir kritis siswa kelas IV SDN Kecandran 01 Salatiga. Jenis penelitian ini adalah Penelitian Tindakan Kelas (PTK). Subjek penelitian ini adalah siswa kelas IV SD dengan jumlah siswa 34 yang terdiri dari 21 siswa laki-laki dan 13 siswa perempuan. Metode penelitian ini menggunakan metode penelitian kuantitatif dan kualitatif dengan instrumen pengumpulan data soal Matematika uraian, observasi, dan dokumentasi. Hasil penelitian ini menunjukkan bahwa penerapan model pembelajaran Think Pair Share (TPS) dengan permainan puzzle untuk meningkatkan kemampuan berpikir kritis Matematika siswa dapat di lihat bahwa hasil nilai kemampuan berpikir kritis kategori tinggi mengalami peningkatan dari pra siklus dan siklus I 35,30 \%, sedangkan peningkatan dari siklus I dan siklus II mencapai $47,64 \%$, untuk berpikir kritis tingkat sedang juga mengalami peningkatan dari pra siklus dan siklus I sebanyak 2,93\%, sedangkan dari siklus I dan siklus II mengalami pengurangan sebanyak $14,7 \%$.
\end{abstract}

\begin{abstract}
This study aims to describe the application of Think Pair Share (TPS) learning model with puzzle games to improve critical thinking skills of fourth grade students of SDN Kecandran 01 Salatiga. This type of research is classroom action research. The subjects consisting of 21 male students and 13 female students. This research method uses quantitative and qualitative research methods with instruments of mathematical data collection, description, observation, and documentation. The results shouws that the value of critical thinking skills in the high category have increased from pre-cycle and the first cycle for $35.30 \%$, while the increase from cycle I and cycle II reached by $47.64 \%$, for critical thinking medium level also increased from pre cycle and cycle I as many as $2.93 \%$, while from cycle I and cycle II experienced reduction of $14.7 \%$.
\end{abstract}

\section{A. LATAR BELAKANG}

Sebagai salah satu materi dalam pendidikan, Matematika memegang peranan penting untuk pengembangan kemampuan berpikir siswa. Hal tersebut sesuai dengan salah satu tujuan pembelajaran Matematika pada jenjang pendidikan dasar dan tingkat menengah yang dimuat dalam tujuan pembelajaran Matematika dalam Kurikulum 2013 adalah untuk mengembangkan kemampuan siswa dalam memahami konsep Matematika.Peningkatan pembelajaran Matematika di sekolah terus diupayakan untuk meningkatkan kualitas prestasi belajar siswa (Susanto, 2018:17).Demikian pula tujuan yang diharapkan dalam pembelajaran Matematika oleh National Council of Teachers of Mathematics (NCTM). NCTM (2000:43) menetapkan lima standar kemampuan Matematis yang harus dimiliki oleh siswa, yaitu 
kemampuan pemecahan masalah (problem solving), kemampuan komunikasi (communication), kemampuan koneksi (connection), kemampuan penalaran (reasoning), dan kemampuan representasi (representation). Menurut Rosmaiyadi (2017: 12) tujuan pembelajaran pada kurikulum 2013 adalah untuk mencapai High Order Thinking (HOT) kemampuan berpikir tingkat tinggi sejak dini salah satunya berpikir kritis. Menurut Purba (2015: 1) berpikir kritis merupakan proses berpikir yang cukup kompleks, sehingga kemampuan berpikir siswa perlu dilatih sehingga mampu berpikir dengan kritis. Sedangkan menurut Jacob dan Sam (2008 dalam Kelana,2014:3) mendefinisikan ada 4 tahapan proses berpikir kritis dalam pemecahan masalah (1) klarifikasi, yaitu tahap siswa merumuskan masalah dengan tepat dan jelas, (2) asesment, yaitu tahap siswa menemukan pertanyaan yang penting dalam masalah, (3) inferensi, yaitu tahap siswa membuat kesimpulan berdasarkan informasi yang telah di peroleh, (4) strategi, yaitu tahap siswa berpikir secara terbuka dalam menyelesaikan masalah.

Berdasarkan hasil wawancara dengan guru kelas IV di peroleh informasi bahwa dalam proses pembelajaran matematika siswa cenderung pasif tidak aktif bertanya saat proses pembelajaran berlangsung. Saat guru menjelaskan materi pembelajaran pada mata pelajaran matematika kebanyakan siswa hanya diam mendengarkan, namun ketika guru bertanya tentang materi yang disampaikan siswa tidak dapat menjawabnya.Hal ini dapat dilihat dari data hasil nilai ulangan harian pada mata pelajaran matematika siswa yang mencapai nilai KKM sebanyak 18 siswa dengan presentase $52,94 \%$ dan siswa yang belum mencapai nilai KKM sebanyak 16 siswa dengan presentase 47,06\% . Rendahnya jumlah siswa yang mencapai nilai KKM pada mata pelajaran matematika tentunya diakibatkan kurangnya berpikir kritis siswa terhadap mata pelajaran matematika.

Berdasarkan uraian permasalahan di atas mengungkap bahwa mendorong peneliti untuk melaksanakan penelitian yang bertujuan untuk menerapkan model pembelajaran Think Pair Share dengan permainan puzzle untuk meningkatkan kemampuan berpikir kritis Matematika

\section{B. TINJAUAN PUSTAKA}

1. Matematika

Menurut Johnson dan Rising (1972 dalam Ismunamto, 2011: 2) mengemukakan mengenai matematika yaitu: a) matematika adalah pola berpikir, pola mengorganisasikan pembuktian yang logis .b) matematika itu adalah ilmu tentang pola, keteraturan pola atau ide. c) matematika adalah bahasa yang menggunakan istilah yang didefinisikan dengan cermat, jelas dan akurat, diwujudkan dalam simbol, lebih berupa bahasa simbol mengenai ide dari pada mengenai bunyi. d) matematika adalah pengetahuan tentang bentuk yang terorganisasi. Sifat-sifat atau teori-teori itu dibuat secara deduktif berdasarkan unsur-unsur yang didefinisikan atau tidak didefinisikan, sifat-sifat atau teori-teori yang sudah dibuktikan kebenarannya. Sedangkan menurut Qisthiani Nasikhah (2011:2) Matematika merupakan bahasa simbolis yang berfungsi untuk mengkomunikasikan hubungan kuantitatif dan keruangan dalam konteks nyata. Siswa dapat memahami konsep secara jelas dan memudahkan dalam berpikir dengan belajar matematika.

Jadi dapat disimpulkan bahwa Matematika adalah ilmu yang membahas pola atau ide tentang keteraturan suatu masalah yang diwujudkan dengan simbol berdasarkan sifat-sifat yang telah di buktikan kebenarannya.

\section{Think Pair Share (TPS)}

Menurut Arends (2008: 15) Think Pair Share (TPS)merupakan suatu cara yang efektif untuk membuat variasi suasana pola diskusi kelas. Semua diskusi yang terjadi membutuhkan pengaturan untuk mengendalikan kelas secara keseluruhan.Pembelajaran Think Pair Share (TPS) salah satu model pembelajaran kooperatif yang memiliki prosedur yang diterapkan secara eksplisit. Siswa diberikan cukup banyak waktu untuk berpikir, merespon dan saling membantu satu sama lain. Dalam pembelajaran ini guru hanya berperan sebagai fasilitator, sehingga kesempatan guru untuk memberikan suatu materi dalam waktu pembahasan relatif singkat.Setelah itu dilanjutkan oleh siswa untuk memikirkan secara mendalam.

Jadi dapat disimpulkan bahwa bahwa Think Pair Share(TPS) merupakan suatu model pembelajaran yang kegiatannya dilakukan secara berkelompok dan masing-masing anggota kelompok menyelesaikan suatu masalah dengan cara individu terlebih dahulu 
lalu mencari kelompok yang memiliki masalah yang sama untuk berdiskusi.

\section{Berpikir Kritis}

Menurut Edward Glaser (1941 dalam Fisher, 2008: 3) berpikir kritis merupakan (1) suatu sikap mau berpikir secara mendalam tentang masalahmasalah dan hal-hal yang berada dalam jangkauan pengalaman seseorang, (2) pengetahuan tentang metode-metode pemeriksaan dan penalaran yang logis, dan (3) semacam suatu keterampilan untuk menerapkan metode-metode tersebut. Berpikir kritis menuntut upaya keras untuk memeriksa setiap keyakinan atau pengetahuan asumtif berdasarkan bukti pendukungnya dan kesimpulan-kesimpulan lanjutan yang diakibatkannya.

Menurut Qomariyah(2017:49), matematika merupakan alat untuk mengembangkan cara berpikir dan merupakan pengetahuan yang berkenaan dengan konsep-konsep yang diatur secara logis maka dalam penerapannya dibutuhkan intelegensi.

Jadi dapat di nyatakan bahwa berpikir kritis merupakan pemikiran yang masuk akal, mendalam, terampil dan reflektif terhadap masalah yang telah terjadi.

\section{Pengertian Puzzle}

Menurut Dominika Yanti (2014:3) Puzzle merupakan sebuah permainan menyusun potonganpotongan gambar pada kotak-kotak kosong. Dengan hasil pemikiran yang kreatif media puzzle dapat digunakan untuk media atau metode dalam pembelajaran.

\section{METODE PENELITIAN \\ 1. Jenis Penelitian}

Jenis penelitian yang dilakukan peneliti adalahPenelitian Tindakan Kelas (PTK). Penelitian PTK memiliki tujuan untuk memperbaiki kinerja pendidik menyangkut kualitas proses pembelajaran, dan meningkatkan hasil belajar peserta didik, baik dari aspek akademik maupun nonakademik.

\section{Subjek Penelitian}

Subjek dari penelitian tindakan kelas ini yaitu siswa kelas IV SD dengan jumlah 34 siswa yang terdiri dari 21 siswa laki-laki dan 13 siswa perempuan.

\section{Teknik Pengumpulan Data}

Teknik pengumpulan data yang digunakan peneliti yaitu non tes dan tes, dalam penilaian non test instrumen yang digunakan adalah lembar observasi yang digunakan untuk mengukur keterlaksanaan proses pembelajaran sesuai dengan model pembelajaran yang digunakan. Sedangkan penilaian yang menggunakan teknik tes instrumen yang digunakan adalah soal dalam bentuk uraian yang kemudian jawaban dari soal uraian tersebut yang nantinya dijadikan dasar untuk mengukur kemampuan berpikir kritis siswa.

Sebelum dilakukan penerapan model pembelajaran, terlebih dahulu soal diuji validitas, reliabilitas, dan tingkat kesukaran di kelas yang lebih tinggi dari kelas yang akan dibuat penelitian. Soal evaluasi diberikan diakhir pelaksanaan pada setiap siklusnya, sebelum dilaksankannya penelitian seorang peneliti melaksankan pra diklus yang di laksankan pada hari Jum'at tanggal 1 Februari 2019, selanjutnya melaksankaan evaluasi siklusI dilaksanakan pada hari Kamis tanggal 14 Februari2019 dan evaluasi siklus II dilaksanakan pada hari Rabu tanggal 20Februari 2019.

\section{Instrumen Pengumpulan Data}

Instrumen yang digunakan untuk mengumpulkan data dalam penelitian ini adalah lembar observasi kegiatan guru di dalam kelas dan lembar observasi kegiatan siswa di dalam kelas saat di lakukannya pembelajaran untuk meningkatkan kemampuan berpikir kritis siswa, serta lembar soal Matematika uraian guna mengukur kemampuan berpikri kritis yang dilakukan di setiap siklusnya.

\section{HASIL DAN PEMBAHASAN}

\section{Kondisi Awal Pra Siklus}

Sebelum dilakukannya tindakan penelitian,peneliti terlebih dahulu melakukan observasipada kegiatan pra siklus dengan tujuan untuk melihat kondisi awal siswa sebelum dilaksanakannya tindakan melalui model pembelajaran Think Pair Share (TPS). Pada kegiatan pelaksanakan pra siklus peneliti menyelenggaran $\mathrm{pra}$ test pada mata pelajaran matematika materi bangun datar terlebih dahulu, berdasarkan hasil pre testhasil dari nilai kemampuan berpikir kritis matematika sejumlah siswa 34, terdapat 6 siswa yang memiliki kemampuan berpikir kritis tinggi, sedangkan 9 siswa memiliki kemampuan berpikir kritis sedang dan 19 siswa memiliki kemampuan berpikir kritis rendah. Nilai kemampuan berpikri kritis siswa dapat dilihat selengkapnya pada Tabel 1 di bawah ini: 
Tabel 1. Nilai Kemampuan Berpikir Kritis Siswa Pra Siklus

\begin{tabular}{clcr}
\hline No & Kategori & Jumlah Siswa & Persentase \\
\hline 1 & Tinggi & 6 & $17,64 \%$ \\
\hline 2 & Sedang & 9 & $26,48 \%$ \\
\hline 3 & Rendah & 19 & $55,88 \%$ \\
\hline
\end{tabular}

Berdasarkan Tabel 1 di atas hasil kondisi pra siklus dapat di lihat bahwa nilai kemampuan berpikir kritis siswa kelas IV SD masih rendah. Nilai kemampuan berpikir kritis siswa disajikan pada Gambar 1 berikut ini:

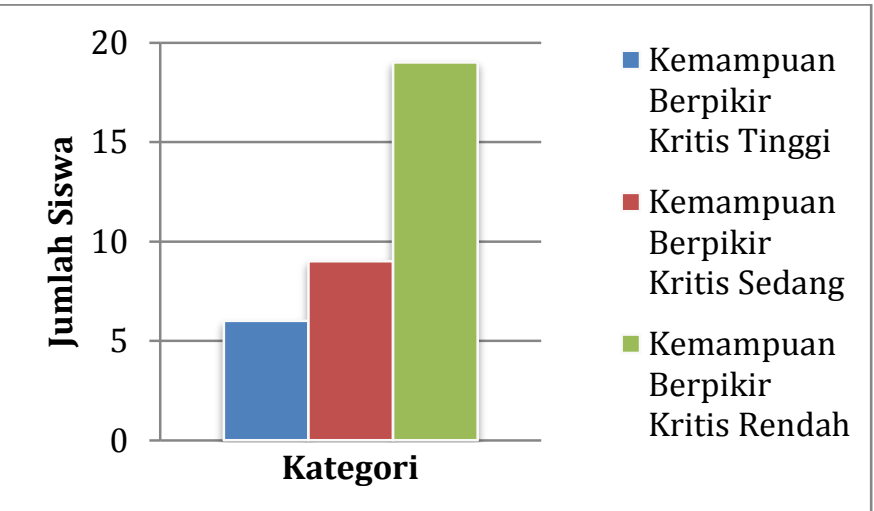

Gambar 1. Nilai Kemampuan Berpikir Kritis Siswa Pra Siklus

\section{Hasil Siklus I}

Siklus I dilaksanakan dalam 3 pertemuan tatap muka dengan alokasi waktu pada setiap pertemuan adalah 3 x 35menit. Nilai kemampuan berpikir kritis siswa dengan model pembelajaran Think Pair Share(TPS)dengan permainan puzzle memperolehhasil sebagai berikut ini:

Tabel 2. Nilai Kemampuan Berpikir Kritis Siswa Siklus I

\begin{tabular}{clcr}
\hline No & Kategori & Jumlah Siswa & Persentase \\
\hline 1 & Tinggi & 18 & $52,94 \%$ \\
\hline 2 & Sedang & 10 & $29,41 \%$ \\
\hline 3 & Rendah & 6 & $17,65 \%$ \\
\hline
\end{tabular}

Berdasarkan Tabel2 di atas dapat dilihat bahwa nilai kemampuan berpikri kritis siswa pada mata pelajaran matematika siswa kelas IV SD meningkat di bandingkan dengan nilai kemampuan berpikir kritis pada pra siklus. Dapat dilihat nilai kemampuan berpikir kritis siswa di sajikan dalamGambar 2 berikut:

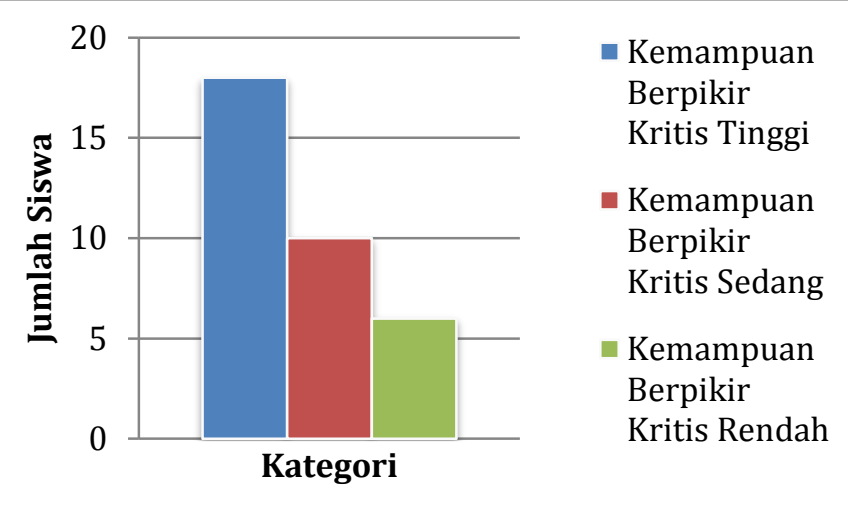

Gambar 2. Nilai Kemampuan Berpikir Kritis Siswa Siklus I

\section{Hasil Siklus II}

Dari hasil yang telah di dapat, peneliti ini melanjutkan dengan mempersiapkan siklus 2 yang bertujuan untuk memperbaiki nilai kemampuan berpikir kritis siswa pada mata pelajaran Matematika. Nilai kemampuan berpikir kritis siswa siklus 2 dengan model pembelajaran Think Pair Share( TPS ) dengan permainan puzzle memperolehl hasil sebagai berikut:

Tabel 3. Nilai Kemampuan Berpikir Kritis Siswa Siklus II

\begin{tabular}{clcr}
\hline No & Kategori & Jumlah Siswa & Persentase \\
\hline 1 & Tinggi & 24 & $70,58 \%$ \\
\hline 2 & Sedang & 5 & $14,71 \%$ \\
\hline 3 & Rendah & 5 & $14,71 \%$ \\
\hline
\end{tabular}

Berdasarkan Tabel 3 di atas dapat dilihat bahwa nilai kemampuan berpikri kritis siswa pada mata pelajaran matematika siswa kelas IV SD meningkat di bandingkan dengan nilai kemampuan berpikir kritis pada siklus I. Dapat dilihat nilai kemampuan berpikir kritis siswa di sajikan dalamGambar 3 berikut:

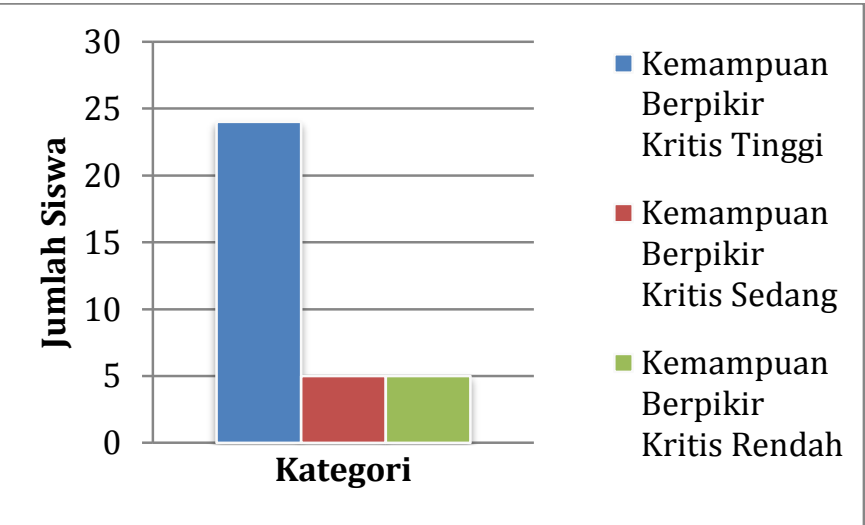

Gambar 3. Nilai Kemampuan Berpikir Kritis Siswa SiklusII

Berdasarkan Gambar 3 di atas dapat dilihat, bahwa nilai kemampuan berpikir kritis siswa pada mata pelajaran matematika mulai dari kondisi awal sebelum dilakukannya tindakan sampai dilakukan 
tindakan tahapan siklus I dan siklus II sudah meningkat.

Penelitian ini dilaksanakan 3 kali pertemuan di setiap siklusnya dengan alokasi waktu setiap pertemuannya adalah 3 X 35 menit. Pada setiap siklus menerapkan model pembelajaran Think Pair Share (TPS) dengan permainan puzzle sesuai dengan materi yang akan di sampaikan yaitu tentang bangun datar.

Peneliti menggunakan nilai ulangan harian untuk digunakan sebagai sampel nilai matematika guna mengetahui sejauh mana nilai Matematika di kelas IV. Sebelum dilakukan penelitian, terlebih dahulu dilakukan pra test untuk mengetahui kondisi awal kemampuan berpikir kritis siswa sebelum dilakukannya tindakan atau penggunakan dengan model pembelajaran Think Pair Share (TPS). Setelah peneliti menganalisis hasil pra test dapat dilihat bahwa kemampuan berpikir kritis siswa masih rendah, sehingga perlu dilakukan tindakan selanjutnya yaitu siklus I. Pada siklus I peneliti telah melakukan penerapan model pembelajaran Think Pair Share (TPS dengan baik dan lancar, pemberian materi pembelajaran di laksanakan di pertemuan pertama dan pertemuan kedua. Pada pelaksanaan pembelajaran menggunakan sintak dari model pembelajaran Think Pair Share (TPS) dengan menggunakan media puzzle, untuk evaluasi siklus I dilaksanakan pertemuan ketiga, setelah peneliti melaksanakan evaluasi selanjutnya mengalisis hasil evaluasi siklus I untuk di bandingkan dengan hasil pra test atau pada kondisi awal kemampuan berpikir kritis siswa sebelum di laksanakannya tindakan siklus I. Akan tetapi hasil evaluasi siklus I sudah meningkat tapi belum sesuai dengan kriteria indikator ketercapaian, oleh karena itu peneliti melanjutkan pelaksanaan tindakan siklus II.

Pada pelaksanaan siklus II dilaksanakan sama dengan siklus I, untuk pelaksanaan siklus II berjalan lebih baik di bandingkan dengan siklus I, pembelajaran lebih tertata teratur dan siswa melakukan permainan puzzle sudah sangat baik dan paham akan peraturan yang telah di buat. Untuk hasil evlasui siklus II sudah meningkat dibandingkan dengan siklus I.

Dapat dilihat bahwa penelitian yang telah dilakukan, diperoleh peningkatan kemampuan berpikir kritis dari pra siklus nilai kemampuan berpikir kritis kategori tinggi 6 siswa atau 17,64\% dari jumlah keseluruhan, 9 siswa memiliki kemampuan berpikir kritis sedang atau 26,48\% dari jumlah keseluruhan, 19 siswa memliki kemampuan berpikir kritis rendah atau 55,88\% dari jumlah keseluruhan, sedangkan saat peneliti melakukan siklus I hasil kemampuan berpikir kritis siswa berubah menjadi 18 siswa yang memiliki kemampuan berpikir kritis tinggi atau 52,94\% dari jumlah keseluruhan, 10 siswa memiliki kemampuan berpikir kritis sedang atau 29,41\% dari jumlah keseluruhan. 6 siswa memliki kemampuan berpikir kritis rendah atau $17,65 \%$ dari jumlah keseluruhan, selanjutnya pada tahap siklus II yang telah di selenggarakan oleh peneliti hasil kemampuan berpikir kritis semakin meningkat dengan hasil 24 siswa yang memiliki kemampuan berpikir kritis tinggi atau 70,58\% dari jumlah keseluruhan, 5 siswa memiliki kemampuan berpikir kritis sedang atau $14,71 \%$ dari jumlah keseluruhan. 5 siswa memliki kemampuan berpikir kritis rendah atau $14,71 \%$ dari jumlah keseluruhan.

Perbandingan kemampuan berpikir kritis siswa pra siklus, siklus I, siklus II dapat di lihat dalamGambar 4berikut ini:

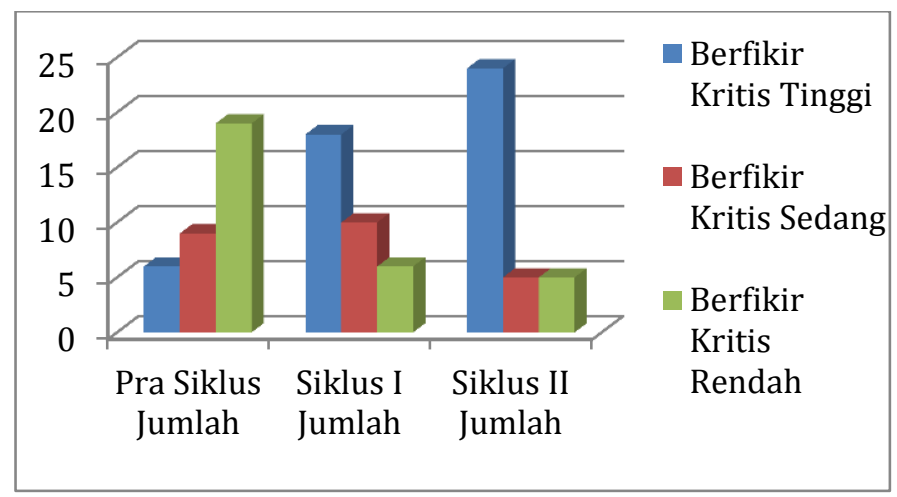

Gambar 4. Nilai Kemampuan Berpikir Kritis PadaPra Siklus, Siklus I, dan Siklus II

\section{E. SIMPULAN DAN SARAN}

Penerapan model pembelajaran Think Pair Share (TPS) dengan permainan puzzle untuk meningkatkan kemampuan berpikir kritis dapat meningkatkan nilai pada mata pelajaran Matematika kelas IV SD, hal ini terbukti bahwa setiap nilai kemampuan berpikir kritis dengan kategori tinggi, sedang dan rendah mengalami peningkatan.

Dapat di lihat bahwa hasil nilai kemampuan berpikir kritis kategori tinggi mengalami peningkatan dari pra siklus dan siklus I mencapai 12 siswa atau 35,30\%, sedangkan peningkatan dari siklus I dan siklus II mencapai 6 siswa atau 47,64\%, untuk berpikir kritis tingkat sedang juga mengalami peningkatan dari pra siklus dan siklus I sebanyak 1 
orang atau 2,93\%, sedangkan dari siklus I dan siklus II mengalami pengurangan sebanyak 5 siswa atau $14,7 \%$.

Berdasarkan simpulan di atas, maka peneliti menyarankan beberapa hal yaitu: Sebaiknya siswa lebih semangat dalam mengikuti proses pembelajaran, serta sebaiknya siswa juga lebih memperhatikan hal-hal yang guru jelaskan, kemudian harapannya siswa sebaiknya lebih aktif dan tidak malu saat bertanya maupun menjawab pertanyaan. Dalam proses pembelajaran guru dapat menerapakan model pembelajaran Think Pair Share(TPS) dengan permainan puzzlesebagai model pembelajaran yang bervariasi agar siswa dalam mengikuti proses pembelajaran tidak merasa bosan dan jenuh.

Banyak model-model pembelajaran yang dapat diterapkan pada proses pembelajaran dikelas seperti model pembelajaran Think Pair Share(TPS) yang dapat diterapkan di SD untuk meningkatkan kemampuan berpikir kritis siswa khususnya pada mata pelajaran Matematika.

\section{REFERENSI}

Arends Richard I. (2008).Learning To Teach. Yogyakarta: Pustaka Pelajar.

Fisher, A. (2008). Berpikir Kritis Sebuah Pengantar. Jakarta: Penerbit Erlangga.

Ismunamto, A. (2011). Ensiklopedia Matematika I. Jakarta: PT Lentera Abadi.

Kelana, M. 2014. Proses Berpikir Kritis Siswa Kelas V SDN Sidorejo Lor 03Salatiga dalamPemecahan Masalah Matematika pada Materi Pecahan. Repository UKSW, 3.

Khomsoh, R. (2013). Penggunaan Media Puzzle Untuk Meningkatkan Hasil Belajar Siswa Dalam Pembelajaran Ilmu Pengetahuan Sosial di Sekolah Dasar. Jurnal Penelitian Pendidikan Guru Sekolah Dasar, 1(2), 1-11.

National Council of Teachers of Mathematic (NCTM). (2000). Principle and Standards for School Mathematics. United State of America: The National Council of Teachers of Mathematics.

Purba, R. T. (2015). Sebuah Tinjauan Mengenai Stimulus Berpikir Kritis bagi Siswa Sekolah Dasar. Jurnal Pendidikan dan Kebudayaan, 5(3), 59-64.

Nasikhah, Q., \& Sapti, M. (2011). Eksperimentasi Model Pembelajaran TPS(Think Pair Share) terhadap Prestasi Belajar Matematika ditinjau dari Kemampuan Komunikasi Matematika Siswa Kelas VII SMP Se-Kecamatan Purworejo. Jurnal Matematika dan Pendidikan Karakter dalam Pembelajaran, 6(3), 388399.

Qomariyah, S. (2017). Hubungan antara Kemampuan Penalaran dengan Komunikasi Matematis Terhadap Pretasi Belajar Matematika.Jurnal Teori dan Aplikasi Matematika, 1(1), 49-53.
Rosmaiyadi, R. (2017). Analisis Kemampuan Berpikir Kritis Matematis Siswa Dalam Learning Cycle 7eBerdasarkan Gaya Belajar. Jurnal Aksioma, 6(1), 1219.

Susanto, M. (2018). Penerapan Metode Permainan Dalam Meningkatkan Prestasi Belajar Matematika Di Kelas IV SD Negeri Menyosok Kecamatan Praya Timur. Jurnal Teori dan Aplikasi Matematika, 2(1), 17-25. 